\title{
EXPOUNDING PROPHETIC BUILDING PRINCIPLES ON THE SITE LAYOUT RE- DESIGN OF CONTEMPORARY RESIDENTIAL NEIGHBORHOODS
}

\section{H. M. Babangida}

Department of Architecture

Ahmadu Bello University, Zaria,

Kaduna State, Nigeria

babanhamza@gmail.com

\begin{abstract}
The prophetic building principles (PBP) in this paper refer to building precedents in which the prophet of Islam applied in the construction of various building typologies. This paper went a step further to demonstrate how they could be expounded in the site layout designs of contemporary housing neighborhoods to achieve a satisfactory environment for Muslims. A triangulation of literature search and case study methods were adopted as the guiding methodology. The case study was used to demonstrate how the PBP was expounded in the redesign of the site layout of the Sardauna housing estate in Katsina. The first PBP expounded in the redesign results in the introduction of Friday mosque, daily prayer mosques, and educational institutions, while the second was achieved through overall redesign of the initial layout from the gridiron to the cluster layout concept. The third PBP of promoting a classless community was achieved by placing residents of different socioeconomic status together within a cluster. The last PBP has affected the management of the ecosystem. It was achieved through the provision of multiple sources of water to sustain wildlife and plants, provision of additional walkways, reduced walking distances, and reduced tarred roads. This study shows that contemporary site layouts of residential neighborhoods could be designed in line with Islamic values and yet achieves universally acceptable design criteria.
\end{abstract}

\section{KEYWORDS:}

Prophetic building principles; Site Layout; Design; Katsina; Quran; Hadith

\section{INTRODUCTION}

"Indeed the principles that Islam has set up for the life and built environment of Muslims which are explored in this study could be treated as criteria against which the planning and designs of modern physical environment could be tested... utilized in determining a satisfactory environment for Muslims." [1]

What are the prophetic building principles (PBP)? These are principles that Islam has set up and became necessary to be applied and implemented in the Muslim urban environment to achieve Islamic objectives of the built environment and to enhance the principles of Islamic social framework. The outcomes of mechanisms used in interpreting and applying the value system of the Islamic legal system referred to as Figh, in Islamic buildings and urban development processes [2]. In the context of this paper, these principles relate to the building precedence as exemplified by the prophet of Islam to promote the spiritual, social, and economic values of residents. Historically, these principles came to the fore after the prophet's emigration (Hejra) from Mecca to Medina (formerly Yathrib) over one thousand four hundred and forty years ago. The Hejra provided physical settings for the first-ever prophetic building process when the prophet had cause to partake in the construction of his mosque (Masjid al- nabawi) to serve as the spiritual and administrative center of a new Islamic state [3].

Further socioeconomic needs of companions lead to the implementation of more of such principles in the construction of other community mosques, markets (Suq), and residential quarters, a trend that was later replicated all over Muslim city-states [2][4][5][6]. The application of these principles was responsible for the uniformity in the form and character of cities such as Damascus, in Syria, Cordoba in Spain, Basra, Kufa, and Baghdad in Iraq and Tunis on the African continent [7], [8]. Among the key of urban elements replicated in such cities according to the implementation of the PBP include Friday mosque (Masjid al-Jummah), daily prayer mosques (Masjid al-jomaa), educational institutions (Medrasas) markets (Suq) and other shared communal facilities such as open spaces.

Based upon the experiences drawn from the application of the PBP in the traditional Islamic cities and housing neighborhoods, practitioners concerned with the Islamic built environment later tested these principles on new projects as well as in the redevelopment of existing ones [1]. This paper seeks to contextually bridge a gap of what a 'before and after scenarios' could have been on expounding the PBP. A site layout of housing was designed based on the modern-day design criteria. It was redesigned integrated to the PBP 
so that the designers could get the benefit from the two scenarios of 'what was' and 'what could have been' using PBP.

\section{CONTEXTUALIZING 'NEIGHBOR' AND 'RESIDENTIAL NEIGH- BORHOODS' FROM ISLAMIC PERSPECTIVE}

A neighbor is a 'person whose house located close to another's house as well as 'closeness or proximity of two residences' [9]. This definition was drawn from the word 'al-jar' from the root word 'jawara,' which connotes the meaning of living or inhabiting a place by two or more people side-by-side to each other. Although this definition was concise, the extent of the words 'close' or 'closeness' was unclear. Two popular opinions were expressed on what constitutes 'close' or 'closeness.' The first was shown by Maliki school of thought, who opines that residents qualify as neighbors (close) so long as they were not separated by the large river while living side by side, facing each other or prayed in one mosque [10].

On the other hand, al-Shafi and Hambali schools considered the extent of neighborliness as 'forty houses in every direction.' In this paper, the neighbor shall be taken as people who live not beyond forty houses from each direction, and specifically those that offer prayer in the same mosque together. Islamic residential neighborhood (Hay or "harah) is considered as the residential context, which facilitates the existence and provides conducive living of human populations to promote the observance and projection of Islamic social values among residents.

\section{THE SARDAUNA HOUSING NEIGHBORHOOD, KATSINA; AN OVERVIEW OF EXTANT SITE LAYOUT}

The Sardauna housing estate lies on Latitude $12^{\circ}$ $56^{\prime} 33.53^{\prime \prime} \mathrm{N}$ and longitude $7^{\circ} 36^{\prime} 27.84^{\prime \prime} \mathrm{E}$ in Katsina, the capital of Katsina State, Nigeria. The housing estate was located along Dutsinma- Batsari roads and sandwiched between two public institutions, Katsina University to the west, and a public library to the south. As shown in Figure 2, the housing estate was designed using the gridiron system and provided with facilities such as shopping areas, schools, small daily prayer mosques (Khamsu Salawat), children's playground, green areas, and spaces for a police station and a clinic. The estate consists of 510 houses of two and three bedrooms, and one hundred and four undeveloped plots allocated to individuals and corporate bodies for private development interventions. In the site layout, four plots sizes were provided; $450 \mathrm{~m}^{2}, 600 \mathrm{~m}^{2}, 750 \mathrm{~m}^{2}$, and $1600 \mathrm{~m}^{2}$. In terms of total perimeter coverage, the space area allocated for children playground had the highest footprint area followed by plots for secondary, primary and nursery schools and shopping in that order. The neighborhood shopping was located at the center of the site layout, while plots provided for mosques were located on three different grids. The Sardauna housing estate was selected for this study among four extant housing neighborhoods in the city of Katsina due to shallow level considerations of PBP on its site layout design.

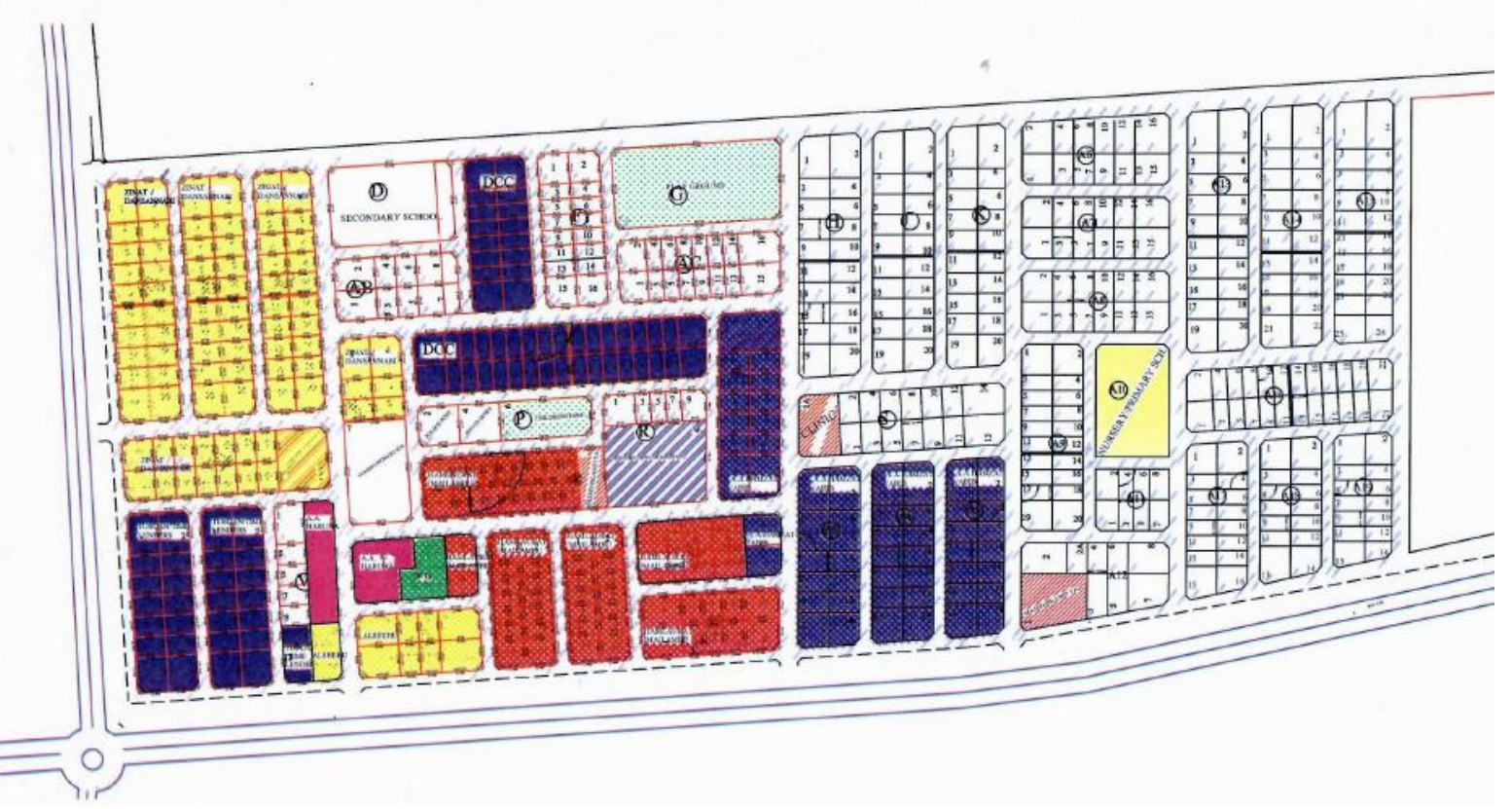

Figure 1. It shows the extent of the Sardauna housing estate Katsina, with its characteristic grid Iron concept. This concept aims to maximize space rather than the well being and promotion of the welfare of urban man as exemplified in Islamic housing site layout designs. (Source; Housing Authority, Katsina State; 2018) 


\section{OBJECTIVES OF THE PAPER}

This paper aims to demonstrate how the PBP could be recycled to achieve a residential neighborhood site layout design that respects the Islamic worldview, yet in line with universal design requirements. Three objectives have become necessary to achieve this aim; to identify the PBP which were applied within the site layouts of Islamic built environments and which gave them their unique characteristics, explain how the use of PBP have affected the site layouts of Islamic built environments, and to demonstrate through a redesign of the site layout of an existing housing estate, how PBP could be used to achieve a residential neighborhood that respects Islamic world views.

\section{AN OVERVIEW OF PROPHETIC BUILDING PRINCI- PLES AND HOW THEY AFFECTED THE FORM OF ISLAMIC RESIDENTIAL NEIGHBORHOODS}

The Muslim faith believed that all actions of the prophet were a result of God's command (see the basis for this in al-Qur'an 53:3-4, 48:8-10, and 4:80). Therefore, the building precedence set by the prophet was considered by them as ordained by God. Many scholars have thus, over the years explained the unique urban forms and housing characteristics in the Islamic built environments as outcomes of the application of PBP [11][12][13][14][15]. For example, the mosque and medrasas served as centers of spiritual and educational advancement for subjects with affect their spiritual, social, economic, and technological progress in this world and the here-after (Din and Dunya). While, in the shopping area, children playground provided a cohesive force in attracting all classes of residents in one place [16] [17]. The housing neighborhoods promote the concept of Ummah among Muslims [18].

The first PBP, which provided the most distinct Islamic characteristic, was the mosque institution. Many verses of the Quran (3:96) and Hadiths (Sahih Muslim Hadith 3 book 5 and 1058 book 4) have provided justifications for the significant roles of the mosque as the center of worship as well as spiritual development of the Muslim faithful. And therefore, facilitates the implementation of Allah's command [19], [20], [21], [22], [23], [24]. This principle was in response to God's command to facilitate the 'Worship Allah alone' as stated in al-Qur'an 51:56 [25][26]. Mosques should be made accessible to all residents and at walking distances to facilitate the attendance of all residents to observe prayers [1]. In compliance with this Hadith and other related ones, the Arab Urban Development Institute developed distances of between $150 \mathrm{~m}-200 \mathrm{~m}$ as walkable distances from any reference house to daily prayer mosque (Masjid al-Jami) and 250m-300m to Friday mosque (Masjid al-Jummah). Due to the significant roles it plays, therefore, in the site layout of residential neighborhoods, the al-Jumaa mosque must be centrally located to achieve equal distances to all residents.

The concept of 'Ummah' among residents is the second PBP, which gave the Islamic housing neighborhoods distinct characteristics. The concept of Ummah aims to promote brotherliness, communality, and participation among Muslims residents living together [8] [27]. Extant Hadiths, among which include in Sahih Bukhari no.6011, elaborated on the benefits of the concept of Ummah among Muslim faithful. This principle was reflected in three ways; provision of equal access to educational institutions achieving compactness in residential houses (use of cluster instead of gridiron) and human scale (encouragement of walking, low rise developments characterized with single or two storey's houses with high population density) [28]. The application of this principle in the site layout of housing neighborhoods has a distinct advantage in addition to promoting communality and participation among residents, also preserve the landscape and ensure ease of access to land for recreation [29].

Moreover, the concept of 'Equality of Muslims before Allah', which is the third PBP, aims to promote socio-economic equality among all classes of residents, i.e., no segregation of residents based on either social or economic status. A reference to al-Qur'an 49:13 was cited as the basis [27]. It was reflected through the provision of traditional Islamic housing neighborhoods The houses of different sizes together in a cluster and around open spaces (afniyah) or cul-de-sac. The provision of similar elevations was devoid the ornamentations, locating markets (Suq), shopping centers, and shops close to the central mosques. The provision of different plot/houses size ensures that the poor can take small lots and live close to those of higher income on larger lots [30], facilitate interactions between different classes of residents; and hence, Islamic society was achieved socially, economically and racially 'classless community' [18].

The last PBP supports the role of man as the Vicegerent (Khalipha) of Allah on earth. The roles of man as vicegerent of Allah include, among others, improvement of the world through the application of the orders and recommendations of Allah amongst people (and other creations) in maintaining the natural balance of creation [31]. These include preservation of water, plants and animal kingdoms and management of the atmosphere, provision of unhindered access to 
natural light, and protection of air quality. An ecosystem in the built environment helps to provide watershed protection, which controls siltation and sedimentation to regulate water flow, storm protection, water supply, and water quality regulation [32]. The four PBP considered in the redesign of Sardauna housing estate includes the role of the mosque as the focal point of site layout, housing compactness, promotion of classless residents, and management of ecosystem. Figure 1 shows the prophetic building principles and the basis from Quran upon which they were built. For example, centrality of the mosque institution was based upon numerous Quranic verses among which include the concepts of worship of Allah, Ummah among residents, Equality of Muslims before Allah, and Role of Man as Vicegerent of Allah.

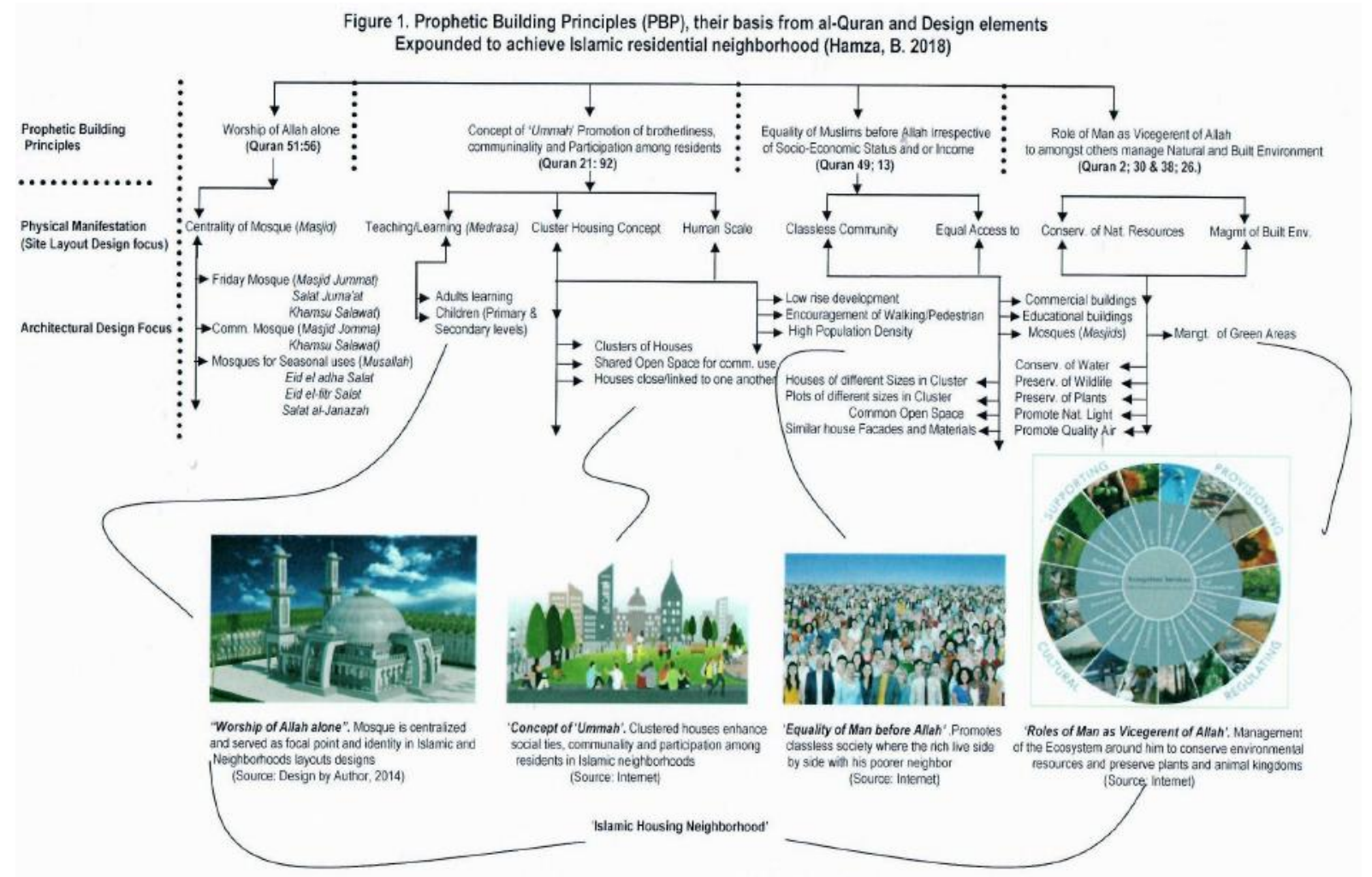

\section{GLOBAL PERSPECTIVES ON RESIDENTIAL NEIGHBORHOOD DESIGN: AN OVERVIEW OF CLARENCE PERRY'S NEIGHBOR- HOOD DESIGN FORMULA}

The much-celebrated neighborhood design formula otherwise developed by Clarence Perry back in the 1920 gave the impetus for the later works, which culminated in search of 'new urbanism' [33]. Although it was later traced back and founded on the footing set in the works of William E. Drummond way back in 1913 [34], it never provided a strong model with which many cities such as Victoria, Bălan, and Motru towns were later developed [35].

Furthermore, it is stated in similitude to the influences of PBP in the traditional Arabic Islamic cities. The concept of this 'new urbanism' as developed by Clarence Perry says that the "Neighborhood Unit" was organized around a central area occupied by a school, major traffic avenues in a perimeter, hierarchical network of internal streets, and shopping areas connected to the main roads.

"Depending on this number, urban cores were created in every town to give each group of people access to all the necessary function."

Although the key areas of semblance were restricted to the centrality of neighborhood institutions such as community center, religious buildings, and halls as well as the provision of easy access to shops and community centers, the contexts; social, economic and spiritual of their various design concern were different [36][37].

First, unlike the concept of 'new urbanism' which aims to achieve equal accessibility by way of centralizing neighborhood institutions, the main focus of the PBP in centralizing Friday mosque and educational institutions was to bring the far residents together periodically to promote harmonious living and to strengthen kinship as sanctioned in Sharia sources. It is an idea that was reflected in various housing clusters.

Second, unlike the neighborhood layout as provided in the Clarence Perrys formula, this relied 
more on the use of the car, while the concept of PBP relied more on a human scale (walkways) and less of reliance on the car. Third, the concept of 'new urbanism' is focusing on the distribution of urban elements. On the other hand, the PBP both detailed the urban elements as well as the residential units as a key constituent of the neighborhood. For example, it encourages living among the rich and the poor together by way of providing different plot sizes, provision of common open spaces for use by the cluster of houses together amongst other housing design considerations.

Finally, many criticisms were leveled against the concept of new urbanism as promoted by Clarence Perry. For example, the famous Isaac's critical commentary of the neighborhood unit [36][38], was its use to provide physical framework in promoting segregation of racial, ethnic, religious and economic groups by private developers willing to utilize the gatedcommunity aspects of the neighborhood units physical design for this purpose. Urban sprawl, as known today, is also attributed to be one of the key consequences of the application of this new urbanism model, especially in many developed cities [39].

\section{METHODOLOGY}

This paper adopted a literature search and case study methods. The literature search was carried out to identify and establish the PBP, which were applied in the traditional Islamic cities and residential neighborhoods and which informed their distinct forms and characteristics. The site layouts, the architectural elements, and their characteristics of extant traditional
Islamic housing neighborhoods were reviewed to understand the contexts in which the principles were applied as they relate to the Quran and Hadith. In line with the objective of this paper of expounding these principles in redesigning the existing housing neighborhood, the Sardauna housing estate in Katsina was selected as a case study due to low-level compliance of PBP on its site layout. Although, before choosing this case study, four other existing site layouts were. The outcome of the redesign undertaking demonstrated 'before' and 'after' scenarios, showing the current site layout and the final redesign site layout in which the PBP was expounded. Thus, the four PBP which was earlier identified from the literature were applied in the redesign of Sardauna housing neighborhood; the concept of 'Worship of Allah alone,' the concept of 'Ummah among Muslims, 'Equality of Man before Allah' and 'Roles of Man as Vicegerent of Allah.' In the final redesign outcome of the initial site layout design, the first PBP was achieved by providing equal access to the mosque and educational institutions. The second and third PBPs were, however, completed in the redesign of the overall site layout from the gridiron to cluster system in which open spaces were created at intervals, as well as the provision of plots of different sizes within the same cluster so that socioeconomic status could live together. The last PBP was achieved through effective management of the natural and built environments in terms of conservation of water, protection of wildlife, plants, and promotion of quality air and access to natural light to residents.

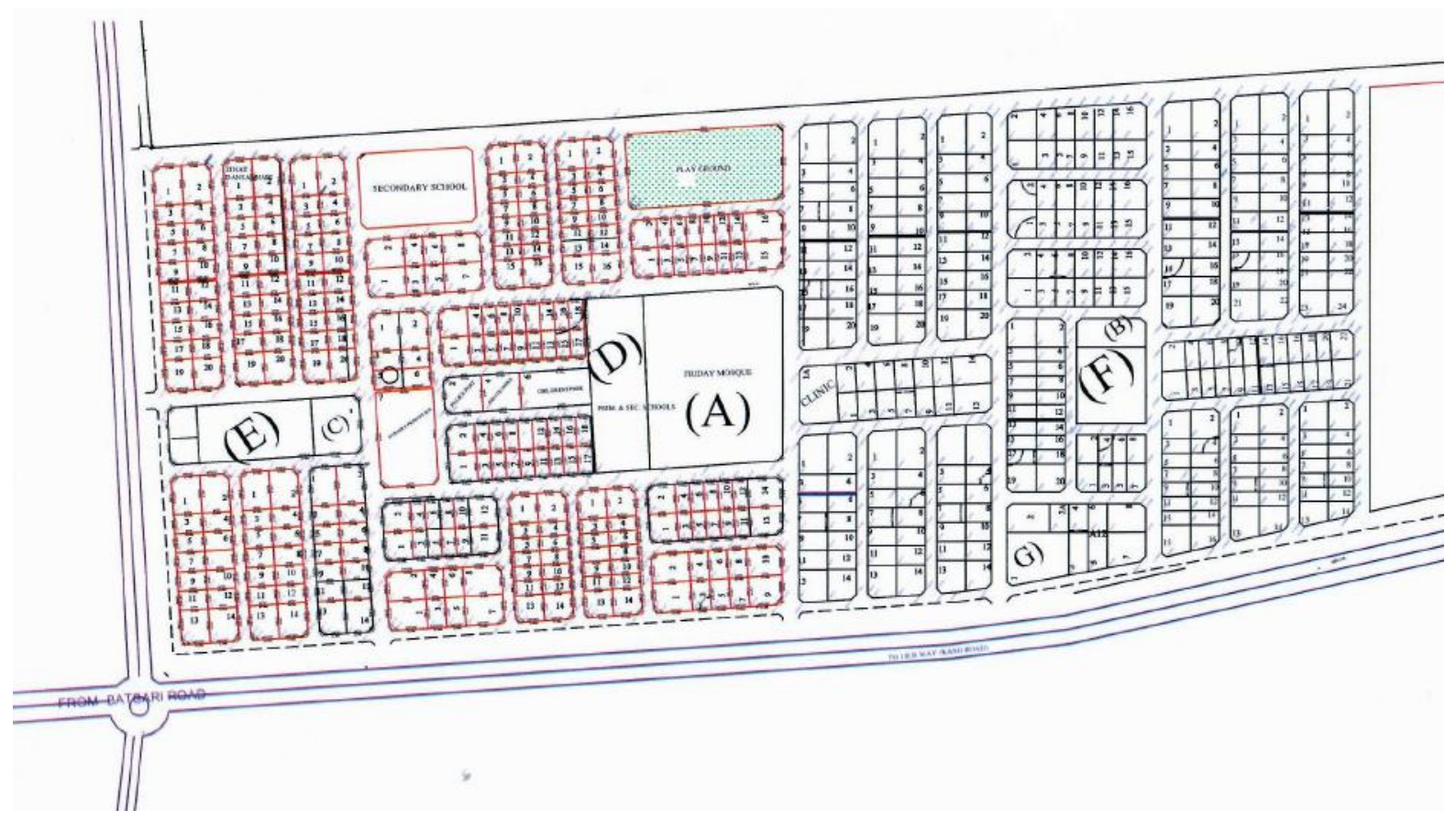

Figure 3. Showing Friday mosque (A) (Masjid al-Jummah) at the center. It also shows two other daily prayer mosques (B\&C) (Masjid Jom$\mathrm{ma}$ ), one each on East and West at approximately equal distances from the Friday mosque. Notice also educational institutions (D, E \&F) attached to the mosques to provide equal accessibility to all residents. This arrangement establishes the Friday mosque as the focal point in the design of Islamic housing neighborhoods. (Source: Redesigned by Author, 2018) 


\section{DATA PRESENTATION AND DISCUSSION: HOUS- ING NEIGHBORHOOD REDESIGN OUTCOME BASED ON PROPHETIC BUILDING PRINCIPLES}

The first design task of expounding the principle of "Worship of Allah alone' on the initial housing site layout design was the location of the central mosque. It is at a centralized location and was allocated the largest space area than any other element as shown in Figure 3. The Friday mosque $(A)$ was strategically located at a distance of $270 \mathrm{~m}$ to the East, 300m (West), 17m (North), and 150m (South) of the site layout. Moreover, the locations of the other daily prayer mosques (B\&C) (masjid jomma) were changed to new distances of $230 \mathrm{~m}$ (East) and $181 \mathrm{~m}$ (West) from the Friday prayer mosque and at length of $225 \mathrm{~m}$ and $218 \mathrm{~m}$ for masjid (B) and $251 \mathrm{~m}$ and $186 \mathrm{~m}$ for masjid (C), to the northern and southern directions respectively so that walkable distances could be achieved. The initial design provided an approximate perimeter area of 3,910m2 for the two daily prayer mosques/medrasa/Islamiyya schools. In the new design however, the Friday mosque alone was allocated a space area of $27,846 \mathrm{mz}$, in addition to combined space areas of 5,120m2 provided for the two daily prayer mosques making a total perimeter area of $32,966 \mathrm{~m} 2$ for all three mosques. Similarly, the educational institutions were placed side by side with mosques. Primary and secondary schools attached to Masjid al-Jummah and other mosques to Masjid Jomaa to achieve equal access to all residents. Overall, the spaces occupied by mosques and schools in the redesigned site layout affected thirty plots at the center (A \& D) and six plots (E), while space provided for nursery and primary schools (F) on the initial site layout were maintained. The perimeter areas for formal schools were increased from $23,309.25 \mathrm{mz}$ to $27,861.98 \mathrm{~m} 2$, indicating an increase of 16.34 percent. However, the plot initially provided for masjid/ Islamiyya $(\mathrm{H})$ has been redesigned to residential plots.

The second PBP expounded on the initial site layout redesign is the 'concept of 'Ummah,' which aims to promote brotherliness, communality and participation among residents, which was through a complete redesign of the overall initial site layout design from the gridiron to cluster layout concept. It involves the conversion of all 'grids of houses' to 'clusters of houses,' as shown in Figure 4. In the clusters, between four to seven houses were put together provided with a common open space to facilitate interaction among residents. A total of five hundred and sixty-one (561) of plot spaces were achieved using this concept on the final site layout indicating an increase of $12.2 \%$. Plot spaces for secondary school (S), playground (PG), Nursery /primary school (N/P), and masjid/Islamiyya $(\mathrm{MI})$ in the initial site layout were redesigned to residential plots.

Furthermore, a total number of 101 open spaces (shaded black in Figure 4) were achieved, indicating an average of one cluster for the use of between four to seven houses. Similarly, the 'human scale aspect' as part of the second PBP, was achieved in three ways; low rise development, reduced number of tarred roads and increase in the number and lengths of walkways in the new site layout. For example, there were forty

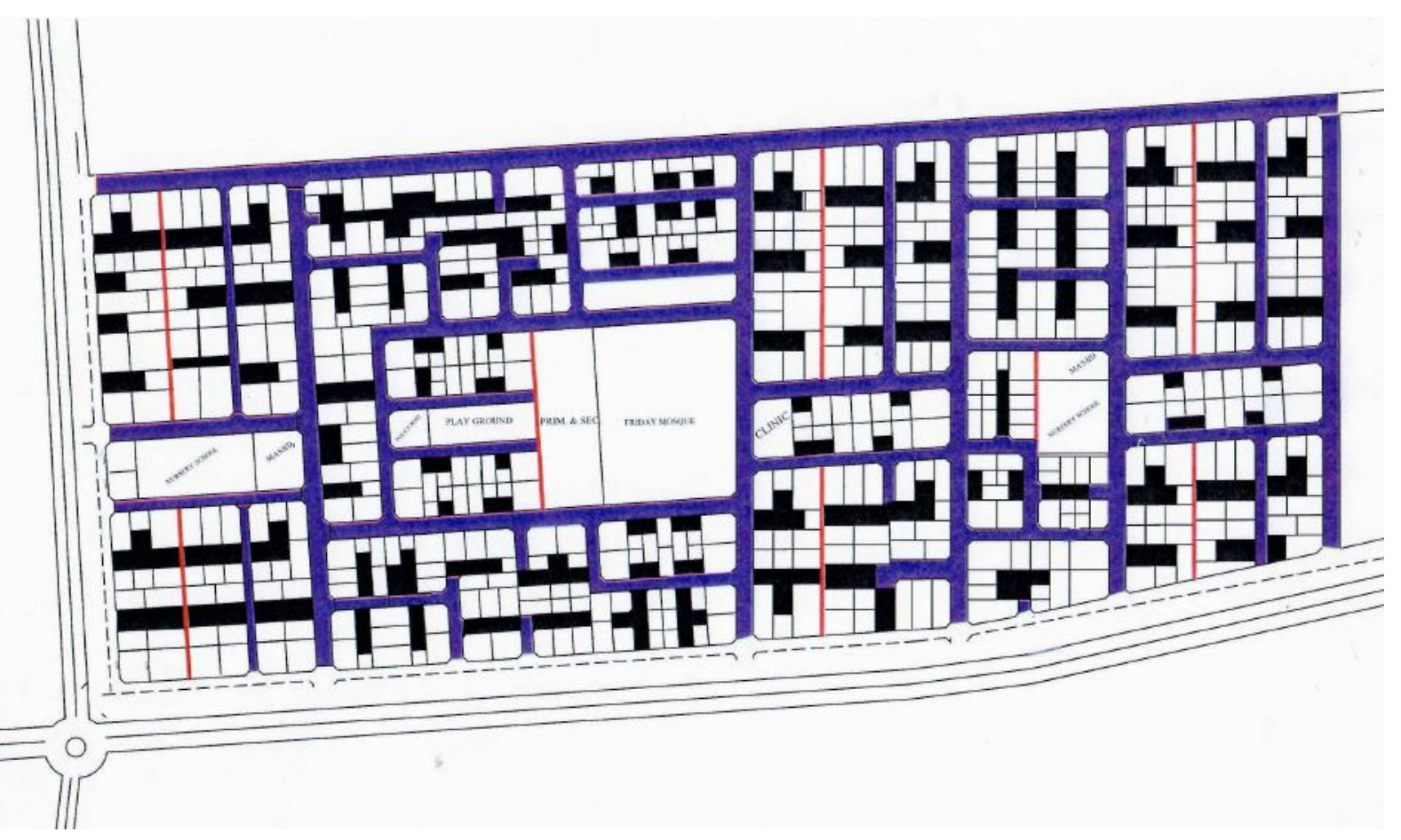

Figure 4. The redesigned Site layout from Gridiron to Cluster housing pattern to achieve the concept of 'Ummah.' The concept of Ummah aims to promote social cohesion, brotherliness, communality and participation among residents, an essential requirement on Islamic housing neighborhoods. (Source; Redesign by Author, 2018) 
three (43) roads (shaded blue in Figure 4) of different hierarchies having a total length of $8,943.39 \mathrm{~m}$, or 9.0 $\mathrm{Km}$ within the initial site layout while in the redesigned site layout, this number was reduced to twenty six (26) with total length of $5,872.4 \mathrm{~m}$ or about $6.0 \mathrm{Km}$ indicating a reduction of 16 roads or $37 \%$ and a decrease of $3,070.99 \mathrm{~m}$ or $34.3 \%$ in lengths of the roads respectively. Moreover, the walkways distances (shaded red in Figure 4) were also increased from total length of 660 meters on the initial site layout to $1,464 \mathrm{~m}$ achieving an increase of more than twice as provided in the initial site layout. Additionally, the walkways provided were strategically located along horizontal routes of between $250 \mathrm{~m}$ to $300 \mathrm{~m}$ and linked to clusters to encourage walking among residents.

The third PBP seeks to promote 'Equality of Muslim before Allah' irrespective of their socioeconomic statuses and or income within the context of the built environment. In general, this involves the creation of a physical framework in which a community devoid of social or economic advertisement is created; a concept referred to as 'classless community.' In the new site layout for example, commercial areas were located close to schools and the mosques, as shown in Figure 5. There are only three shopping areas were provided in the initial site layout in the newly redesigned site layout. However, a total of five commercial areas were provided indicating an increase of $40 \%$ in the number of shopping centers to enhance accessibility to residents. These include two shopping areas $\mathrm{SH} 1$ \& $\mathrm{SH}_{2}$ and one each to the west $\mathrm{SH}_{3}$, east $\mathrm{SH}_{4}$ ) and south ( $\left.\mathrm{SH}_{5}\right)$ of the Friday mosque and primary/ secondary school, respectively. All five shopping areas have a total area of $20,403.72 \mathrm{~m}^{2}$, a threefold (300\%) increase on the initial site layout.

Additionally, unlike in the gridiron concept which puts together similar plot sizes together across the grid, achieving 'classless community' involves putting together plots/houses of different sizes together within the same cluster. For example, while in the initial site layout, plot sizes range between $450 \mathrm{~m}^{2}$ (15M X $30 \mathrm{M})$ to $1248 \mathrm{~m}^{2}(26 \mathrm{~m} \mathrm{X} \mathrm{48M})$ in the redesign of the site layout. However, the smallest plot size was reduced from $450 \mathrm{~m}^{2}$ (15m X 30m) to $225 \mathrm{~m}^{2}$ (15m X 15m in green color) and the biggest plot $1200 \mathrm{~m}^{2}$ (30M $\mathrm{x}$ $40 \mathrm{~m}$ in brown color). In between these two, three other plot sizes were proposed which include $450 \mathrm{~m} 2$ (15M×30m), 600m2 (20M×30m), and $900 \mathrm{~m}^{2}$ (30m X $30 \mathrm{~m})$. In this redesign therefore, residents of different income groups would have access to the different plots sizes based on their income levels. It is also applied to the houses, whereby residents with bigger houses live side by side with those who could afford smaller ones.

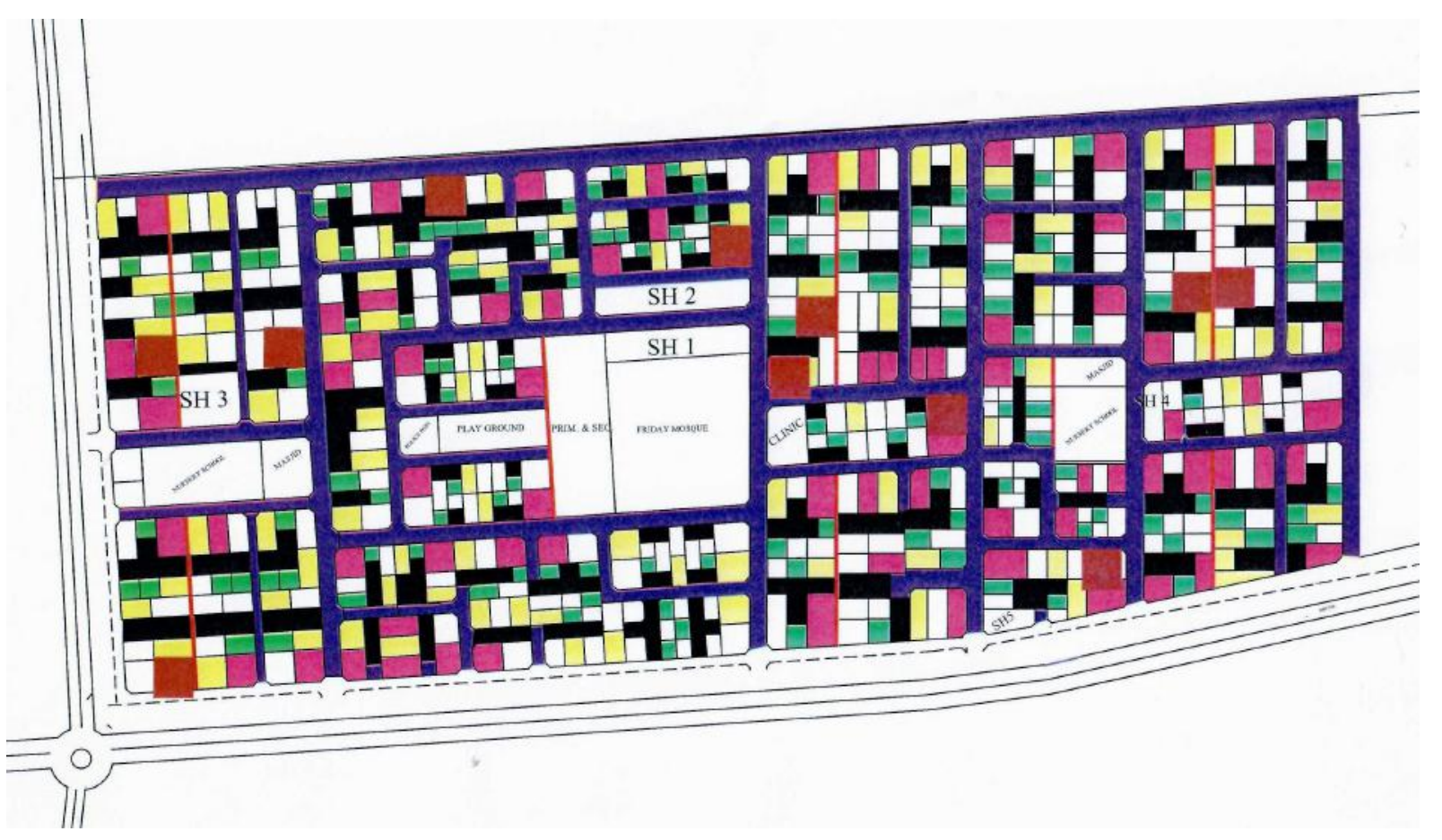

Figure 5. Showing redesigned site layout in which plots/houses of different sizes were put together within the same cluster and equal access to infrastructure was achieved. The concept of 'Equality of Muslims before Allah' aims to create a 'classless community' in which residents live side by side to each other irrespective of their socio-economic statuses. (Source: Redesign by Author, 2018) 
The additional architectural design was proposed in the new site layout design to address the design challenges of the proposed smallest plot size of $225 \mathrm{mz}$. It is to augment the two other prototype designs proposed for actual construction on the initial site layout. As shown in Figure 6 (a-c), the first design (a) is the new proposed house while (b) and (c) were the designs provided in the initial site layout. The new architectural design is a one-bedroom flat (a) proposed for the lowest income group. It consists of a single bedroom, living room and other facilities such as kitchen, store and two toilets, one for guests and the other for the family. Furthermore, the new proposal was designed to have the same footprint areas of the living room, first bedroom and its toilet, guest toilet, corridor and lobby with the two bedrooms flat (Figure $5 b$ ). However, the kitchen $(Z)$ was relocated and reduced in size from $10.332(3.230 \mathrm{mX} 3.200)$ to $8.63 \mathrm{~m} 2$ (2.25m X $3.83 \mathrm{~m})$.

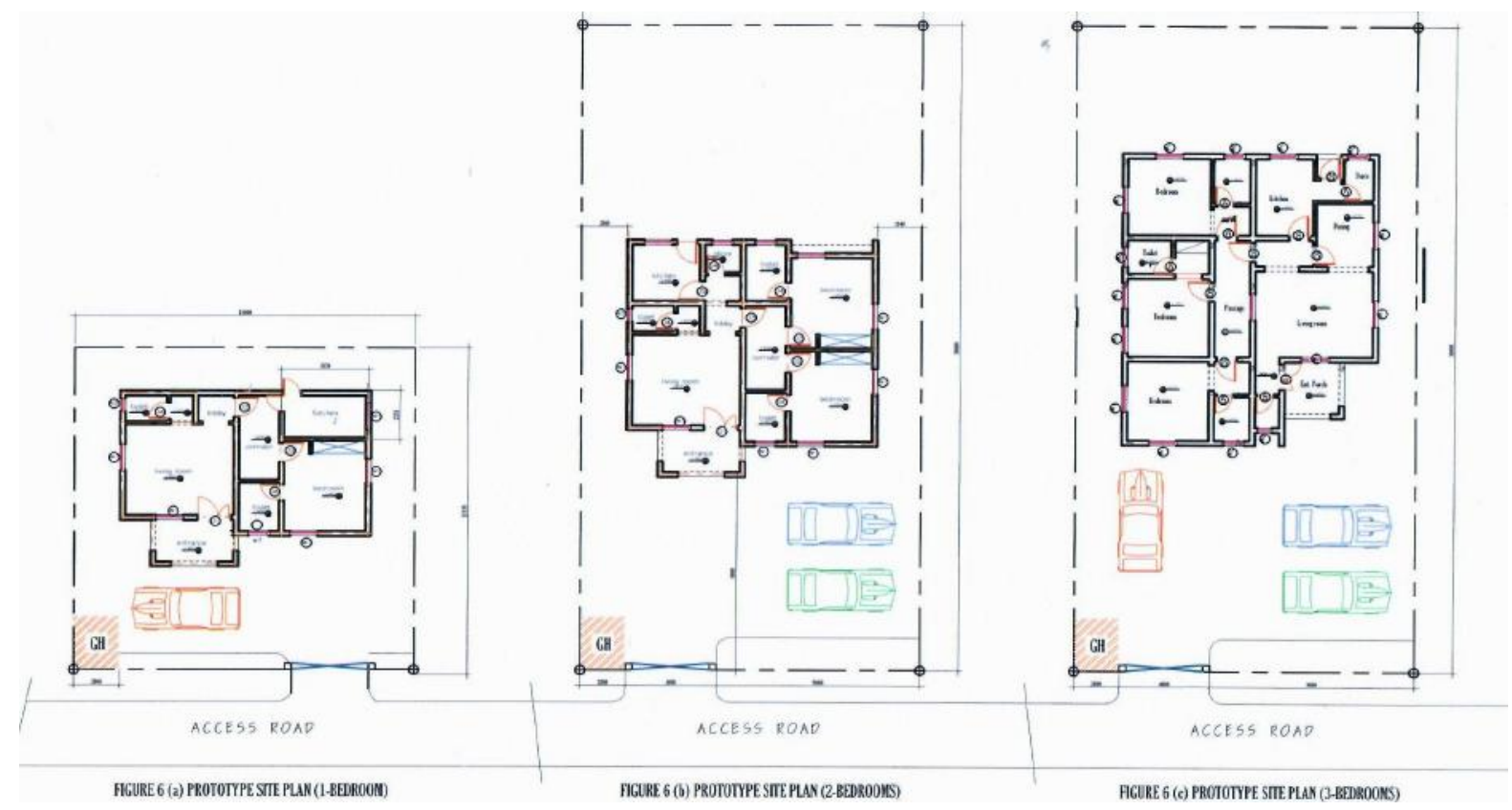

Figure $6(\mathrm{a}-\mathrm{c})$. Showing an architectural design proposal of a one-bedroom apartment (a) to address requirements for the lowest income group on the plot size of $225 \mathrm{mz}$, and to maintain uniformity of design with the two and three bedrooms, (b \& c) the proposed house has same footprint area of living room, first bedroom, and its toilet, guest toilet, corridor and lobby. (Source: Design by Author, 2018)

The last PBP considered in the redesign of the Initial site layout ('Role of Man as Vicegerent of Allah') brought out the responsibility on how man manages his environment as the vicegerent of Allah. Some of the man's roles captured within the context of the paper include how he achieves prudency in water use, conserves, and preserves bionetwork and plants within his environment. Basic Information such as the details on how to achieve prudence in use of water, design approaches, and elements to preserve bionetwork, landscaping details on recommended types of plants, trees and shrubs were not provided in the initial site layout. Hence, in the redesigned of the site layout, the first strategy was to encourage alternative sources of water (wells or boreholes) and which should be reticulated at the site layout, cluster, and individual houses levels. The second and third steps include the provision of adequate water storage facilities (surface or underground/or both) to service the entire housing estate. In this way, the water from public water was dedicated only for domestic activities such as drinking, preparing food, bathing, washing clothes and dishes, watering the yard and garden, while the water from the alternative sources should be used for managing the natural environment such as gardening, landscaping the streets, and clusters and serving as reservoir. It was partly achieved. In the new site layout design, as shown in Figure 7 (a), this indicates the recommended locations of water storage facilities (WF) and the alternative water source (BH1). Their locations together gave a unique advantage of supplying water directly to water points along main streets $\left(\mathrm{BH}_{2}\right)$ and at the cluster level ( $\mathrm{BH} 3)$. A specially designated water container was placed at various intervals of between ten to twenty meters intervals along streets and clusters to ensure availability of water for the use of wildlife such as lizards, birds, and insects such as butterflies and pollinators within the landscaped areas. Moreover, shrubs and trees which require very little water for survival such as neem tree (Azadirachta Indica) or cypress are suggested for planting along the main streets. 


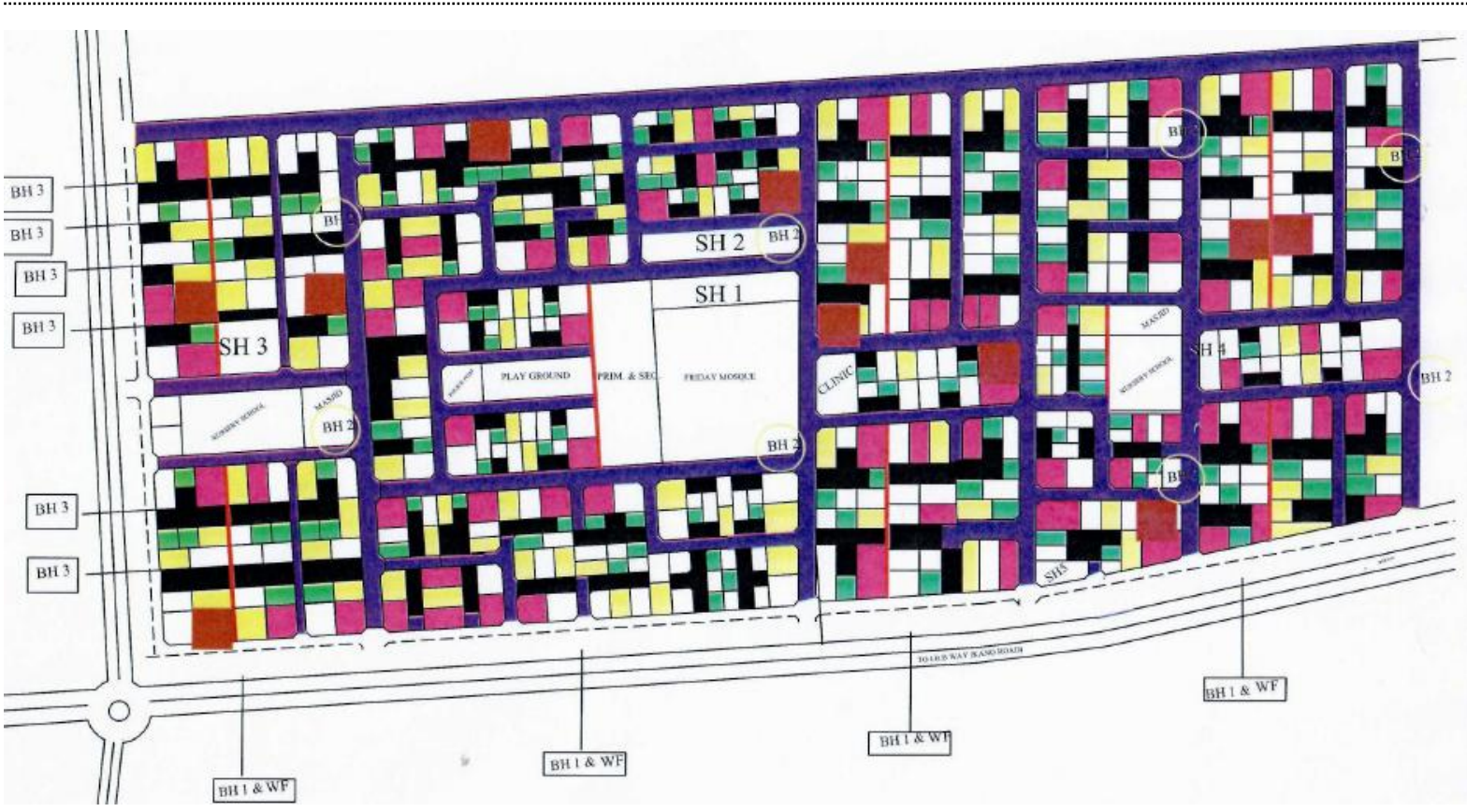

Figure 7. Shows the alternative water source (BH1) and locations of water storage facilities (WF) put together to ensure the availability of water and prudence in use. Water points along main streets $\left(\mathrm{BH}_{2}\right)$ provide sustenance for wild animals and plant's survival. (Source: Redesign by Author, 2018)

THE DESIGN SUMMARY: INITIAL SITE LAYOUT DESIGN VERSUS THE FINAL REDESIGN OUTCOMES

The contents of the initial and the final site layout design were compared in Figure $8(\mathrm{a} \& \mathrm{~b})$ below. As shown in Figure 8(a), the initial site layout design was based on the gridiron concept, while the new redesign (Figure $8 \mathrm{~b}$ ) was based on the cluster concept. In the initial site layout design, plots of similar sizes were placed on the same grids. The shopping area was centralized, while the three mosques were provided, and the educational institutions were spread across the layout without any known Islamic design criteria. In the redesign of the site layout, the Friday mosque was recognized as the main focus of the site layout.
Meanwhile, the cluster of housing concept was adopted to achieve social cohesion, brotherliness, communality, and participation among residents. It is key to the ingredient of the Islamic housing neighborhood design. Furthermore, the third PBP was expounded in the final site layout design by creating a 'classless community' in which the rich and his poorer neighbors live together with equal access to common facilities. Meanwhile, the last PBP was achieved through a reduction in the number of roads provided on the site layout. Also, it increases the walkable routes and provision of multiple sources of water for efficient management of the natural and built environment.

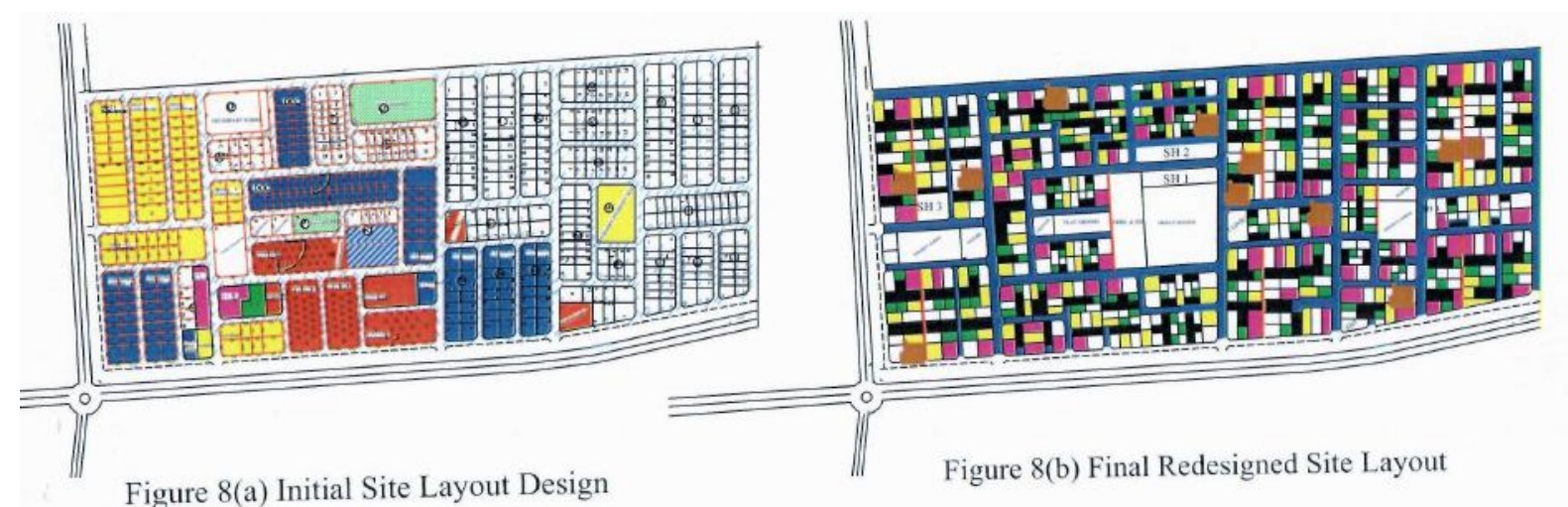

Figure 8 (a \& b). Showing the 'before' and 'after' scenarios of use of prophetic building principles. Key differences between the two scenarios include consideration of the mosque (Masjid Jummah) as the focus of the housing neighborhood, use of cluster concept, putting up of plots of different sizes in the same cluster instead of shopping area which was used as the focus of the housing estate in (b), in place of the use of gridiron concept, placement of similar plot sizes on the same grid as shown in (a). (Source: Redesign; Author, 2018) 


\section{CONCLUSIONS}

It has been explained that possibilities exist to apply PBP in the site layout design of contemporary housing neighborhoods, yet without negating universal design concerns. While a strict land-use determinism and maximization were the aim of the site layout, the final design, however, centered more on promoting the wellbeing and welfare of the urban man. As discussed previously, many benefits were derivable from site layouts designed while drawing inspiration from the prophetic building principles. The Friday mosque, which was located at the center of the site layout, provides avenues for all residents to meet at least once a week (during Salatul Jummah), while the community mosques facilitate meetings among neighbors at least twice in a day (during Subh and Ishaa prayers). These meetings, thus informal, provides avenues for delivering new information and knowledge on the social, economic, health status of individual residents and to arrive at a unanimous decision when the decision-making affects the overall progress. Similarly, the distribution of community mosques in the site layout based on the walkable distances helps to avoid overcrowding of worshippers on a particular mosque at the expense of the others, as well as save up parking spaces in the mosque area which will have otherwise necessitated the use of automobile to the mosque by residents.

Consequently, residents will save money from savings in fuel use, reduces the carbon content in the air as a result of walking rather than using the automobile to the mosque, promote their health status pursuant to daily physical exercise as a result of walking to and from the mosque. Likewise, the location of formal schools close or attached to mosques enhances the spiritual upbringing of school children as they will be participating in prayer sessions during school hours. It also eases the tasks of parents to streamline tasks of picking children from school and prayer in the mosque respectively. Streamlining activities together helps residents to focus more on other daily routines by freeing up their time and hence, lower their stress levels. The shopping needs of residents could similarly be streamlined to coincide with prayer times due to the proximity of shops and mosques. The proposed use of all or part of the formal schools in the site layout as medrasas further saves resources by eliminating the need for additional structures for medrasas.

The use of cluster housing concept in the new site layout gave rise to compact houses within a cluster. This particular housing form provides a basis for neighbors to mutually monitor their health statuses, a social and economic condition which in turn prompts participation in the form of assistance among residents themselves. It also encourages residents to share common elements in the cluster, such as open space, shades from green areas and temporary parking spaces. Similarly, the classless community achieved in the new site layout, whereby residents of different socioeconomic status were put in the same cluster with equal access to facilities removes the bad feelings be- tween the rich and the poor and thereby promote mutual respect among them. While people that have attained high social status were found to have impaired key social and emotional skills such as being less interested in connecting with others, less compassionate and less generous, people with lower attainment on the other hand, were known to suffer physical health than those better off, including higher rates of heart disease and depression. Thus, the removal of such social inequalities in residential neighborhood design was expected to promote happiness and spread compassion among residents. Likewise, the use of multiple sources of water was to ensure its availability for domestic use and efficient management of the ecosystem and to ensure that residents efficiently utilized the water. In particular, the water points which drew from the boreholes were meant to provide water for nurturing plants shrubs and grasses along streets and in clusters, while the water from public water was intended to give individual houses water for domestic activities. Because housing neighborhoods have challenges associated with adequately housing higher numbers of people in most cases beyond the projected population, water and its sources must be objectively used. Similarly, the trees types and shrubs recommended for planting in the site layout was to ensure that they do not only survive and develop in that harsh climatic zone but were also sustainably managed throughout their lifetime; a role that must be performed by man as a true vicegerent of Allah on earth.

\section{REFERENCES:}

[1] H. Mortada, Traditional Islamic Principles of Built Environment; Routeledge Curzon, USA and Canada: Taylor \& Francis, 2003.

[2] B.S. Hakim, Arabic-Islamic cities: Building and planning principles. London: KPI Ltd. 1986.

[3] S. Omer, The Prophet Muhammad (PBUH) and Urbanization of Madinah; Kuala Lumpur: Research Center, International Islamic University. 2005.

[4] N. AlSayyad, "Cities and Caliphs: On the Genesis of Arab Muslim Urbanism, Contributions to the Study of World History 26 (Westport, Conn.: Greenwood Press, 1991)". International Journal of Middle East Studies, vol.25, no.3, pp. 524-526, 1993.

[5] R. Hillenbrand, Islamic architecture: Form, Function and Meaning, ed. by Case Bound, New York: Columbia University Press, 1994.

[6] R. Hillenbrand, Islamic Art and Architecture, London: Thames \& Hudson, 1999.

[7] V. Grunebaum, The Structure of the Muslim Town, in Islam: Essays in the Nature and Growth of Cultural Tradition, London: Routeledge of Kegan Paul, 
1969.

[8] N.A. Akeel, "Urban Design and the Islamic City in the Light of Islamic Values," In An Anthology of Essays on Integrating Islamic Values in the Theory and Practice of Architecture and The Built Environment, Kuala Lumpur: IIUM. 2009

[9] A.A. Sarkawi \& A. Abdullahi, A. "The Principles of Islamic Neighborhood. In Sarkawi \& Abdullahi (Eds)." Islam and Urban Planning. Kuala Lumpur: SP Scholar Press, 2007.

[10] A.M. Ahmad al-Dardir A. M, "Wizarah al-Adl wa alIslamiyya al-Awqaf, Dawlah al-Imarah al-Arabiyya al-Muttahidah", Al-Sharh al-Sogir, Vol. 4, 1989.

[11] B.S. Hakim \& A. Zubairu, "Rules for the built environment in 19th century Northern Nigeria." Journal of Architectural and Planning research, Vol. 23, no. 1, pp. 1-25, 2006.

[12] M. Ahmed, Cities of Islam. Beirut; B.A.U Press, 1971.

[13] S.V. Noe, "In Search of The 'Traditional Islamic City': An Analytical Proposal with Lahore as a Case Example", in Ekistics, vol. 47, no. 280, pp. 69 $-75,1980$

[14] L. Belhaj, "Planning New Towns using Traditional Prototypes," In Abdelbaki \& Hazem (Eds), "Housing in Islamic City," Proceedings of a Symposium, Ankara, Pp. 241. 1984

[15] O. Grabar, "Cities and Citizens," in Bernard Lewis (Eds). The world of Islam; Faith, People, Culture, London: Thames and Hudson, 1994.

[16] E. Abdelrahman, The influence of Hadith on the architecture of early congregational mosques. A PhD Thesis submitted in accordance with the requirements for the degree of $\mathrm{PhD}$, University of Leeds, Institute for Medieval Studies. 2010

[17] Z. Ismawi, Tawhid and Al-Imarah: A Philosophical framework of Architectural and Environmental Design Education, in An Anthology of Essays on Integrating Islamic Values in the Theory and Practice of Architectural and the Built Environment, Kuala Lumpur: IIUM, 2009.

[18] A. F. Moustapha, "Islamic Values in Contemporary Urbanism." In Sarkawi \& Abdullahi (Eds), Islam and Urban Planning. Kuala Lumpur: SP Scholar Press, 2007.

[19] S. Omer, "Rationalizing the Permissibility of Mosque Decoration", Journal of Islamic Architecture, vol. 4, No.1, pp. 14-26, 2016.
[20] A.A. Yassin, \& N. Utaberta, "Architecture in the Islamic Civilization: Muslim Building or Islamic Architecture," Journal of Islamic Architecture, vol.2, no.2, pp. 52-60, 2012.

[21] S.M. Adi \& C. Puspitasari, "Mosque as a Model of Learning Principles of Sustainable Architecture," Journal of Islamic Architecture, vol. 4, no.1, pp. 3336, 2016.

[22] T. Aryanti, Breaking the wall, preserving the Barrier: gender, space, and power in contemporary mosque architecture in Yogyakarta, Indonesia. Submitted in partial fulfillment of the requirements for the degree of Doctor of Philosophy in Architecture in the Graduate College, University of Illinois at Urbana-Champaign, 2013.

[23] H. E. Al Khalifa, The Friday mosque of the Arabian Gulf: defining its spatial and formal languages-19752010, a thesis submitted to Welsh school of architecture Cardiff University in partial fulfillment of the requirements for the degree of doctor of philosophy. 2017.

[24] J. Steele and I. Serageldin, "The architecture of the contemporary mosque: New architectures," London: Academy Editions. 1995

[25] B. S. M. AbulQaraya, "The Civic and Cultural Role of the Sheikh Zayed Grand Mosque," 2nd Global Conference on Business and Social Science-2015, Bali, 2015.

[26] B. S. M. AbulQaraya, B. S. M., The political role of the Mosque, (Unpublished MA thesis) Cairo: Faculty of Economics and Political Science at Cairo University, 1994.

[27] A. Abdurrahim, "Home and the Neighborhood," In An Anthology of Essays on Integrating Islamic Values in the Theory and Practice of Architecture and The Built Environment, Kuala Lumpur: MPH Group Publishing, 2009.

[28] H. Nashabi, "Educational Institutions", In R.B Serjent (Eds), The Islamic City, Paris: Presses Universitaires de France, 1980.

[29] P. K. Asabere, "The Value of Homes in Cluster Development Residential Districts: The Relative Significance of the Permanent Open Spaces Associated with Clusters," The Journal of Real Estate Finance and Economics, vol. 48, no. 2, pp. 244-255, 2014.

[30] H.A. Fathy, The Social Approach to Planning: an application to Islam, Unpublished PhD Dissertation, University of South California, 1988 
[31] Z. Asmawi, “Managing the Environment in Islamic Perspective," In A.A. Sarkawi and A. Abdullah (Eds.), Islam and Urban Planning. Kuala Lumpur: Scholar Press, Pp 90-114. 2007

[32] D.W. Pearce, Economic Value of Ecosystems. Ecosystem Health, Vol. 7 No. 4. Blackwell Science Inc. 2001.

[33] T. B. Banerjee, "Introduction' in Beyond the Neighborhood Unit," in Residential Environments and Public Policy, New York: Plenum Press, p. 1-11, 1984.

[34] D.L. Johnson, "Origin of the Neighbourhood Unit," Planning Perspectives, vol. 17, pp. 227-245, 2002.

[35] A. Panait, "New Towns in Modern Urbanism: Concept \& History," Ion Mincu, Bucharest: Univer- sity of Architecture and Urbanism, 2013.

[36] J. Marsh, Why Inequality Is Bad for the One Percent .https://greatergood.berkeley.edu/article/ item/

why_inequality is_bad_for the_one_percent (downloaded on 20/01/2019). 2012

[37] C. Perry, "The neighborhood unit: A scheme of arrangement for the family-life community," Regional study of New York and its environs, vol. 7, no. 2, pp.140. 1929.

[38] Everett, Haynes, and L.M. Arizona, Why city planners should make water a top priority. https:// www.futurity.org/urban-planning-water-14405122/. (Downloaded 21/01/2019). 2017

[39] J. Richards, "Failure of the New Towns," Architectural Review, vol. 114, pp.29-32. 1953 